\title{
Erector spinae plane block for anesthesia of open ventral hernia repair in severe ankylosing spondylitis
}

\author{
Ciddi ankilozan spondilitte açık ventral herni tamirinin anestezisi için erektör spina \\ alan bloğu
}

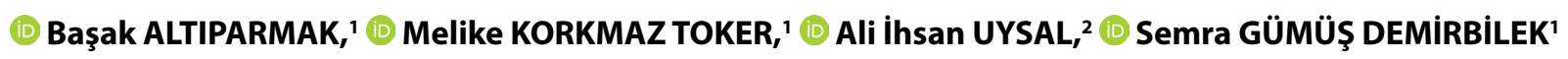

\begin{abstract}
Summary
Ankylosing spondylitis (AS) is a challenging disease for anesthesiologist due its airway and axial skeleton involvement. A 55-year-old male patient suffering from severe AS, admitted to anesthesiology clinic. He was planned to receive a midline open ventral hernia repair. We decided to perform bilateral ultrasound-guided erector spinae plane (ESP) block at the level of T8 with $0.4 \mathrm{mcg} \mathrm{kg}^{-1}$ hour ${ }^{-1}$ dexmedetomidine sedation for complete anesthesia of the surgery. We performed ESP block with $25 \mathrm{~mL}$ of $0.25 \%$ bupivacaine and repeated the same procedure at the contralateral side. Twenty minutes later, the skin incision was started. We did not need to apply an additive anesthetic or analgesic drug throughout the surgery. ESP block provides analgesia for different dermatomes by effecting ventral rami and rami communicantes of spinal nerves depending on the level of injection site. When performed between $\mathrm{T7}$ and T9 levels, it has been reported to effectively attenuate post-operative pain after different types of surgeries.
\end{abstract}

Keywords: Anesthesia; ankylosing spondylitis; erector spinae plane block; ultrasound; ventral hernia repair.

\section{Öz}

Ankilozan spondilit, havayolu ve aksiyel iskelet tutulumu nedeniyle anestezistler açısından zorlu bir hastalıktır. Ciddi ankilozan spondilit yakınması olan 55 yaşındaki bir erkek hasta Anesteziyoloji kliniğine başvurdu. Orta hat açık ventral herni onarımı planlanmıştı. Ameliyatın tam anestezisi için $4 \mathrm{mcg} \mathrm{kg}^{-1}$ saat $^{-1}$ dexmedetomidine sedasyonu ile birlikte T8 seviyesinden bilateral ultrason rehberlikli erektor spina alan (ESP) bloğu yapmaya karar verdik. ESP bloğunu $25 \mathrm{~mL} \% 0,25$ bupivakain ile yaptık ve aynı işlemi karşı tarafta tekrar ettik. Yirmi beş dakika sonra cilt insizyonu başladı. Operasyon boyunca ek bir anestezik veya analjezik ajan uygulamaya gerek duymadık. ESP bloğu, enjeksiyon seviyesine göre spinal sinirlerde ventral rami ve komünikan ramiyi etkileyerek, farklı dermatomlarda analjezi sağlar. T7-T9 seviyeleri arasından uygulandığında, farklı tipte ameliyatlardan sonra etkili şekilde postoperatif ağrıyı azalttığı bildirilmiştir.

Anahtar sözcükler: Anestezi; ankilozan spondilit; erektor spina alan bloğu; ultrason; ventral herni tamiri.

\section{Introduction}

Ankylosing spondylitis (AS) is a challenging disease for anesthesiologist due its airway and axial skeleton involvement. The cervical spine is progressively involved and consequently results in reduced to absent neck movements and flexion deformities. The ankylosis of temporomandibular joints causes reduced mouth opening that makes airway management difficult in AS. ${ }^{[1]}$ Hence, general anesthesia is particularly hazardous in these patients due to the airway and pulmonary involvement. However, subarachnoid block technique is also difficult with obliteration of the intervertebral spaces and syndesmophyte formation, and progressive stiffness, ossification of the axial ligaments. ${ }^{[2]}$

Recently, plane blocks have gained popularity for anesthetic management of patients with AS due to advantages such as safety and simple application. ${ }^{[3]}$

In this case report, we represent the anesthetic management of a patient with severe AS for open ventral hernia repair.

\footnotetext{
'Department of Anesthesiology and Reanimation, Muğla Sıtkı Koçman University, Muğla, Turkey

${ }^{2}$ Department of Anesthesiology and Reanimation, Muğla Sıtkı Koçman University, Training and Research Hospital, Muğla, Turkey

Submitted: 25.07.2018 Accepted after revision: 30.01.2019 Available online date: 25.06.2019
}

Correspondence: Dr. Başak Altıparmak. Kötekli Mahallesi, Muğla Sıtkı Koçman Üniversitesi, Anesteziyoloji ve Reanmasyon Anabilim Dalı, 48000 Muğla, Turkey.

Phone: +90 - 252-214 1323 e-mail: basak_ugurlu@yahoo.com

(c) 2021 Turkish Society of Algology 


\section{Case Report}

A 55-year-old, $65 \mathrm{~kg}$, male patient who has been suffering from severe AS for 31 years, admitted to anesthesiology clinic. He was scheduled for a midline open ventral hernia repair under general anesthesia. Pre-operative anesthetic evaluation revealed a difficult airway with Mallampati Class IV oropharyngeal view, a thyromental distance less than $6 \mathrm{~cm}$ and limited mouth opening capacity. We decided to perform bilateral ultrasound-guided erector spinae plane (US-ESP) block at the level of T8 with dexmedetomidine sedation for complete anesthesia of the surgery. We gave detailed information about the procedure and received written informed consent both for the anesthesia technique and publication of the case. In the operating room, the patient received intravenous $2 \mathrm{mg}$ midazolam for premedication and 2 I $\mathrm{min}^{-1}$ oxygen support with face mask. Dexmedetomidine infusion started with a rate of $0.4 \mathrm{mcg}$ $\mathrm{kg}^{-1}$ hour ${ }^{-1}$ after a $1 \mathrm{mcg} \mathrm{kg}^{-1}$ bolus dose. The patient could not sit because of severe restriction in hip joint movements, so we placed him in lateral decubitus position. We located the US probe (Fujifilm Sonosite, Bothwell, USA) in longitudinal orientation at the level of T8 spinous process and then placed $3 \mathrm{~cm}$ laterally from the midline. Under aseptic conditions, 80 $\mathrm{mm}$ 21-gauge block needle (Stimuplex(R) B-Braun Medical, Melsungen, Germany) was inserted inplane with cranial-to-caudal direction. We injected $2-3 \mathrm{~mL}$ of isotonic saline solution to confirm correct needle tip position and following hydrodissection, we injected $25 \mathrm{~mL}$ of $0.25 \%$ bupivacaine and $4 \mathrm{mg}$ dexamethasone deep to the erector spinae muscle. We repeated the same procedure with another 25 $\mathrm{mL}$ of $0.25 \%$ bupivacaine and $4 \mathrm{mg}$ dexamethasone at the contralateral side for intraoperative anesthesia and post-operative analgesia. Then, the patient was placed in supine position. The sedation level of the patient was assessed by Modified Observer's Assessment of Alertness/Sedation scale with 5 min interval. Twenty minutes later, when the OASS score was 3 (responds only after name is called loudly and/or repeatedly), the skin incision was started. Numerical rating scale scores of the patient were between 0 and 3 and we did not need to apply an additive anesthetic or analgesic drug throughout 35 min operation. We stopped dexmedetomidine infusion before the skin closure. The patient was followed in recovery room for 30 min until his Observer's Assessment of Alertness/Sedation scale (OASS) score increased to 5 (responds readily to name spoken in normal tone/awake). The patient did not request for a rescue analgesic during the first 12 post-operative $h$ in the surgical ward, and then, intramuscular $75 \mathrm{mg}$ diclofenac sodium was applied.

\section{Discussion}

US-guided ESP block was first described in 2016 by Forero et al. ${ }^{[4]}$ and we started to perform this technique for post-operative analgesia after different thoracic and abdominal surgeries in our clinic. ${ }^{[5]}$ USESP block provides analgesia for different dermatomes by effecting ventral rami and rami communicantes of spinal nerves depending on the level of injection site. When performed between T7 and T9 levels, it has been reported to effectively attenuate post-operative pain after different types of abdominal surgeries ${ }^{[6]}$ Recently, Tulgar et al. ${ }^{[7]}$ evaluated the effect of US-ESP for post-operative analgesia in laparoscopic cholecystectomy. Authors reported that US-ESP block significantly reduced pain scores of patients when compared to no intervention group. Moreover, authors reported the use of US-ESP as a surgical anesthesia method for stoma closure of an 86-year-old female patient. ${ }^{[8]}$ Following IV 1 mg midazolam and IV 25 mcg fentanyl sedation, they performed US-ESP block with $20 \mathrm{ml}$ of $0.5 \%$ bupivacaine and $10 \mathrm{ml}$ of $2 \%$ lidocaine mixture. A total of IV $40 \mathrm{mg}$ ketamine was applied throughout 100 min surgery. Similarly, we successfully performed US-ESP block as a surgical anesthesia method for a major abdominal surgery. However, this is the first case reporting the use of US-ESP block for complete anesthesia of a patient with severe AS.

US-guided transversus abdominis plane (TAP) block is another regional anesthesia technique which has been shown to provide effective analgesia after laparoscopic and open ventral hernia repair operations. ${ }^{[9,10]}$ TAP block is frequently used as a part of multimodal analgesia approach to reduce post-operative pain and opioid consumption after larger open surgery of the abdominal wall. ${ }^{[10]}$ However, TAP block has a disadvantage that the onset of sensory block is relatively slow. It takes nearly 60 min to reach maximum effect. ${ }^{[1]}$ Moreover, TAP block is known to provide analgesia to the parietal peritoneum, skin, and muscles of the anterior abdominal wall. ${ }^{[12]}$ However, 
visceral block of nerve fibers is also needed for the complete anesthesia of a large ventral hernia repair.

Previously, we described the anesthetic management of another patient with severe AS for open cholecystectomy surgery. ${ }^{[3]}$ We performed a single shot paravertebral block with $100 \mathrm{mg}$ bupivacaine, however, the block extension remained insufficient and patchy for open cholecystectomy surgery. Hence, they had to perform additional injections from multiple levels for an appropriate surgical site in that case. The spread of anesthetic solution was disrupted during paravertebral block. Therefore, we preferred to perform bilateral US-ESP block for the current case and the block provided sufficient anesthesia with dexmedetomidine sedation.

\section{Conclusion}

Although the result of our patient is promising for anesthetic management of patients with AS, it should be kept in mind that ESP is a plane block and there is still a risk of interindividual variability in the spread of local anesthetic agent and extent of analgesia.

\section{Informed Consent: Written informed consent was ob- tained from the patient who participated in this study.}

\section{Conflict-of-interest issues regarding the author- ship or article: None declared.}

\section{Peer-rewiew: Externally peer-reviewed.}

\section{References}

1. Li JM, Zhang XW, Zhang Y, Li YH, An JG, Xiao E, et al. Ankylosing spondylitis associated with bilateral ankylosis of the temporomandibular joint. Oral Surg Oral Med Oral Pathol Oral Radiol 2013;116(6):e478-84. [CrossRef]

2. Hermann $K G$, Althoff $C E$, Schneider $U$, Zühlsdorf $S$, Lembcke $A$, Hamm B, et al. Spinal changes in patients with spondyloarthritis: Comparison of MR imaging and radiographic appearances. Radiographics 2005;25(3):559-69; discussion 569-70. [CrossRef]

3. Altıparmak B, Uysal Al, Dede G, Turan M, Uğur B. Paravertebral block for the anesthetic management in a patient with severe ankylosing spondylitis: Single injection or multiple injections? J Clin Anesth 2018;44:5-6. [CrossRef]

4. Forero M, Adhikary SD, Lopez H, Tsui C, Chin KJ. The erector spinae plane block. Reg Anesth Pain Med 2016;41(5):621-

7. [CrossRef]

5. Altıparmak B, Toker MK, Uysal Ail, Turan M, Demirbilek SG. Comparison of the effects of modified pectoral nerve block and erector spinae plane block on postoperative opioid consumption and pain scores of patients after radical mastectomy surgery: A prospective, randomized, controlled trial. J Clin Anesth 2019;54:61-5. [CrossRef]

6. Tulgar S, Selvi O, Kapakli MS. Erector spinae plane block for different laparoscopic abdominal surgeries: Case series. Case Rep Anesthesiol 2018;2018:3947281. [CrossRef]

7. Tulgar S, Kapakli MS, Senturk O, Selvi O, Serifsoy TE, Ozer Z. Evaluation of ultrasound-guided erector spinae plane block for postoperative analgesia in laparoscopic cholecystectomy: A prospective, randomized, controlled clinical trial. J Clin Anesth 2018;49:101-6. [CrossRef]

8. Tulgar S, Thomas DT, Deveci U. Erector spinae plane block provides sufficient surgical anesthesia for ileostomy closure in a high-risk patient. J Clin Anesth 2018;48:2-3. [CrossRef]

9. Fields AC, Gonzalez DO, Chin EH, Nguyen SQ, Zhang LP, Divino CM. Laparoscopic-assisted transversus abdominis plane block for postoperative pain control in laparoscopic ventral hernia repair: A randomized controlled trial. J Am Coll Surg 2015;221(2):462-9. [CrossRef]

10. Chesov I, Belii A. Postoperative analgesic efficiency of transversus abdominis plane block after ventral hernia repair: A prospective, randomized, controlled clinical trial. Rom J Anaesth Intensive Care 2017;24(2):125-32. [CrossRef]

11. McDonnell JG, O'Donnell B, Curley G, Heffernan A, Power C, Laffey JG. The analgesic efficacy of transversus abdominis plane block after abdominal surgery: A prospective randomized controlled trial. Anesth Analg 2007;104(1):193-7.

12. Chou R, Gordon DB, de Leon-Casasola OA, Rosenberg JM, Bickler S, Brennan T, et al. Management of postoperative pain: A clinical practice guideline from the American pain society, the American society of regional anesthesia and pain medicine, and the American society of anesthesiologists' committee on regional anesthesia, executive commi. J Pain 2016;17(2):131-57. [CrossRef] 